\title{
A BROAD PERSPECTIVE ON ESTONIAN HAIKU AS COMPARED TO ITS JAPANESE ORIGINS
}

\author{
Kati Lindström
}

\section{The position of haiku in Estonian literary context}

The role of haiku in Estonian literature has so far been somehow neglected. The major treatises on Estonian literary history mention haiku as something that the main Estonian poets have "also" written, but the more thorough analyses about these authors usually do not contain the treatment of their haiku anymore. At the same time writing haiku obtained nearly "epidemic" dimensions during the 1960s and 1970s (cf. Haug 1980, Kaalep 1983, Mäger 1980; Raud 1984), so that the debut collections of the young authors contained almost imperatively a selection of haiku and the few critics who paid attention to this form in their contemporary media, started to complain about haiku's mediocre quality and its focus on barely the formal requirements of the 5-7-5 syllable pattern.

In Estonian literary history the 1960 s are a time of innovation, and this era is characterised by a constant tension between the ideologically correct and dominating social realism and the search for the freedom of poetical expression. The central issue in this aspect was the fierce debate on free verse in media in 1960 and 1961 (Hennoste 1995, Velsker 1998). It has repeatedly been pointed out that due to the constant political censor and the ideological nature of the official paradigm, every kind of literature gained ideological quality and seemingly politically indifferent texts (e.g. poetry about nature) and texts which do not judge but try to convey so-to-say immediate unintellectualised impression (like haiku), also became ideologically determined as a form of opposition (Olesk 1998: 230; Raud 1997; Veidemann 1996).

The role of haiku in legitimising and refreshing modern poetics has been widely known (the case of imagism, also in France, Brazil etc - cf. Miner 1958, Lobo 1995, on the influence of haiku on Rilke see e.g. Shibata 1998). To my mind, those two reasons - the ideological opposition and the necessity for a classical form legitimising the modern poetics - might as well be the main reasons for haiku's popularity in Estonia in1960s and 1970s. All the more that in the second half of the 1980s, when ideological suppression in literature started to fade, haiku becomes a marginality as well.

\section{The material for the present study}

The haiku which serve as basis for the present study were published during 19631998 in the literary magazine "Looming", of which it may be assumed that as the official magazine of the Estonian Writer's Union it published only those texts which were acceptable both to the political system and to the literary public (thus we can

\footnotetext{
${ }^{1}$ Before the World War II haiku practically did not exist in Estonia, except for a couple of publications which have no connection with the later haiku-boom after the war. The first haiku after the war was published in the collection of poems by Ain Kaalep, the first publication of haiku in "Looming" dates from 1963.
} 
follow the process of legitimisation of haiku). Also it is assumed here that in this kind of institutional publication writers published the texts which they considered to be the most prototypical, and that young authors used this magazine (of course besides influential collections of poems) greatly as a poetic primer and derived their own haiku-patterns from these texts. So the texts published here should give us a kind of bird's-eye view of the main characteristics of Estonian haiku. Altogether there are 339 texts from 20 authors in 27 publications.

Still we encounter a set of problems using this material. First: a big part of the material is published at the end of the 1970s and the beginning of the 1980s, not in the 1960 s, perhaps because of the then general editors' personal antipathy towards the form. This shift in time becomes important if we want to define the role of haiku in shaping the modern poetic style, which was evolving especially in the second half of the 1960s and the beginning of the 1970s. Secondly: there is the dominance of three authors (Peep Ilmet, Andres Ehin, Mait Markus) in the body of the material, while some influential haiku-authors (e.g. Viivi Luik) have not published their haiku in "Looming" at all.

In the present article, Estonian haiku is analysed against the background of the classical Bashō-style haiku, the requirements for the content and form of which were set by Matsuo Bashō's collection "Fuyu no hi" ("A Winter's Day")". The later developments of the haiku and its modernisation process have not been considered here.

\section{Is Estonian haiku an open form?}

The two most conspicuous characteristics of haiku for a writer of European background are, first, its shortness, and secondly (actually resulting from the former) its openness in Eco's sense (or its scriptibility in Barthes's sense), which is seen in "validating (or at least not contradicting) the widest possible range of interpretative proposals" (Eco 1981). In Japanese poetics the "Yojö" or "surplus meaning" is a concept, which emerged in Japan in the second half of the Heian era and which mainly means that a poem must have a hinted meaning in addition to the explicitly stated one (Breslavec 1981: 75, also Yamada-Bochynek 1985: 294; Ueda 1970: 161).

Since having an ambiguous meaning is an imperative in Japanese poetics, and due to the antipathy towards using tropes in European sense (tropes formed inside one text), the Japanese have developed some highly elaborated mechanisms of creating additional meanings between the texts, so that any text in the literary canon can become a part of the meaning generation process in any particular poem. Such mechanisms are for example the pivot words (kakekotoba), the allusive variations on the earlier texts (honkadori), alluding to geographical names (utamakura) and of course using the seasonal words (kigo), the canon of which was definitively formed by the practitioners of the haiku genre. For Bashō and his style of haiku, the surplus meanings, associativeness and ambiguity were the merit of a haiku (Ueda 1970: 161163).

Using a seasonal word is also the best known requirement among the haikuwriters from other countries outside Japan. It has become one of the key issues of haiku's so-to-say domestication process, even so far that in Hawaii, where different seasons are practically indistinguishable, the adherents of the orthodox haiku have

\footnotetext{
${ }^{2}$ For an elaborated analysis see for example Ueda 1970, Breslavec 1981.
} 
fixed a set of seasonal words for all the four seasons (Yamada-Bochynek 1985: 445). William Higginson has tried to establish a universal set of the seasonal words, which might be acceptable all over the world (Higginson 1996).

Estonian writers who regard haiku foremost as an aesthetic phenomenon, not as an expression of the Zen principles ${ }^{3}$, take usually nature as their subject matter (as does a significant part of the haiku writers in other national literatures), but there exists also a considerable amount of aphoristic or proverb-like haiku (a tendency that is noticeable elsewhere as well, see Yamada-Bochynek 1985: 447). Of the 339 texts analysed here, about 290 depict nature or at least use the symbolics related to nature, 200 of them can be well considered to refer to a certain season.

Unlike in case of Japanese literature, there is no fixed set of seasonal words in Estonian literature, and thus there also cannot exist fully determined connotative meanings, which the readers are fully conscious of and which therefore could be triggered by using a certain word in a poem. Of course, like in every literature, there exist poetical clichés and traditional tropes in Estonian literature, but these are rarely used as conscious means for generating inter-textual meanings; all the more that this kind of technique presupposes also a reader who would share a common classical repertory (Kawamoto 1992), and who in his/her turn would search for these allusions to other texts from inside the given haiku. Otherwise the allusions to other literary works become just a personal pastime for some readers, who might as well consider it as a "deviation" from the author's "initial meaning".

It is highly interesting that the haiku authors in "Looming" quite often use conventional metaphors, which have been employed depicting nature already since the beginnings of Estonian literature and which might thereby be easily used for alluding to those classical texts. However, being somehow afraid to remain ambiguous, the authors restrict their connotations by drawing explicit connections inside the very text. By this, they often fasten the axiology related to the images used: winter images like "snow", "ice", "pale sky" etc, and autumn images like "leaving birds", "grey sky" often carry a negative connotation and are connected with the metaphors of "sleep" and "death". Summer and spring, on the contrary usually have the positive connotations of "awakening", "life", "light" etc.

For example, Minni Nurme:

Lumehällis vait

uinuvad noored metsad

kord tuleb neil aeg

(In the snow-cradle, quiet / the young woods asleep / once will come their time);

Peep Ilmet:

Tuhakarva veel

tinakarva taeva all

purjetab puuleht

(On the ash-coloured water / under the lead-coloured sky / a leaf is sailing);

Aino Saadik:

Liblikaid pole.

Jäälilledel on külmad, elutud silmad.

(No butterflies. / The frost ferns have cold / lifeless eyes).

\footnotetext{
${ }^{3}$ Though Zen-Buddhism was quite popular in Estonia in the 1960s and the 1970s, the poetics of Estonian haiku continues to be governed to a considerable extent by the principles other than the Buddhist ones.
} 
Although in itself this is a very traditional axiology, it is unfamiliar to the classical Japanese haiku.

While Kawamoto Kōji considers depoeticization or implicit denigration of conventional poetic subjects and poetical clichés as one of the main techniques of imagist poetry (Kawamoto 1993: 9-10), we can trace the same technique of meaning generation only in the works of two authors, Andres Ehin and Sven Kivisildnik, neither of whom belongs to the mainstream of Estonian haiku.

As for the other above-mentioned Japanese techniques for creating an open text, Estonian haiku writers make a prolific use of proper names. Proper names are signs that have "an extensional class for its designatum", and therefore they belong to those signs, which may have only one denotatum (Sebeok 1994: 37). Because of this the use of a proper name in a poetical text evokes a higher level of intimacy, no matter whether the place or person named is familiar to the reader or not (see also Breslavec 1981: 100-101, Lotman 1996: 246-247). Nevertheless, while the names used in Estonian haiku do evoke a complicated set of historical and geographical associations, the orientation towards literary associations like in the case of utamakura in tanka or the place names in haiku is rare. In some cases, however, it is possible to read the place name both literally and as a name for an actually existing place.

A very distinctive group among the Estonian haiku are the texts using paronomasia as a dominating technique. Those texts usually make puns on the basis of the same lexical root in different words, often in conventional metaphors. Extensive use of the internal rhyme is also a productive mechanism for the puns. For example,

Ain Kaalep:

Vaevalt laevadest
môtles jasmiiniõiel
istuv admiral

(Hardly about the ships / was thinking on a jasmine-blossom / sitting admiral - the "admiral" here means both a navy admiral and a sort of butterfly).

Such puns are similar to the earlier, pre-Bashō haiku where the creation of witty puns was a purpose in itself, but again: while Japanese puns are based mainly on literary associations which accompany different readings of the one and the same word, and readers are to arrive to a hinted pun by themselves after reading the text ${ }^{4}$, the authors of Estonian haiku usually give strict guidelines how to understand the text restricting by this the possible range of interpretations.

In my opinion, the reasons for avoiding ambiguity in Estonian haiku might be twofold. The first reason may be that a great part of the authors might have actually been ignorant of how the afore-mentioned techniques work in Japanese literature, as there still exists no commented anthology of haiku in Estonian and the writers had probably derived their knowledge from European and Russian translations of haiku, which might have not been very well commented and therefore not very illustrative in this aspect.

The second and an even more important reason is the heightened sense of individuality in Estonian literature in comparison with the classical Bashō-style haiku. It should be remembered that a classical haiku is an expression of Zen mentality, which requires the author's self not to be manifested in the text. While it is true that in some aspects the subject of Japanese haiku is a description of "natural, concrete, and secular things", that still does not mean that it is "merely or primarily representa-

\footnotetext{
${ }^{4}$ See for example Ueda's treatment of Bashō's early haiku, which actually do not yet belong to the classical Bashō-style haiku established by his later works that have been taken as the basis for the analysis in the present study (Ueda 1970: 37-43).
} 
tional" (Watts 1990: 193): we could rather see it as envisioning the transcendental metaphysical model, not as depicting a concrete object in real time and space (Karatani 1993: 20-21). Zen artist is not in the subject-object opposition with nature and therefore he/she cannot depict it as a landscape or a set of real things, but sees it in their suchness (Karatani 1993: 11-14; Watts 1990: 193-220). Poet "should enter into the external object (the subject of his poem), instead of forcing it to come to him" (Ueda 1970: 168).

Estonian haiku authors, on the contrary, tend to depict their personal emotions or aesthetic experiences in connection with a certain scene of landscape, seeing themselves thereby as something different from the nature (also a noticeable tendency for example in American and Brazilian haiku; see Yamada-Bochynek 1985: 458; Lobo 1995: 101). Even those authors who may claim to be influenced by Zen-Buddhism remain in this aspect faithful to the usual European self-centredness and subjectobject position towards nature ${ }^{5}$. Hence also the ultimate care for conveying author's own idea as adequately as possible. That was further amplified by writer's position in the literal situation in the 1960s and the 1970s, which was that of a dissident, a prophet, an orator of truth (Kaplinski 1983: 235; Hennoste 1995: 88).

\section{The use of tropes in Estonian haiku}

In his article "Rhetoric as a mechanism for meaning generation", Yuri Lotman points out the cultural universal of "rhetoricism/anti-rhetoricism", which means that in those cultures where the rhetorical trend is prevailing, literary standard requires the author to use tropes (in a neutral literary text), while in the anti-rhetorical culture the authors prefer to avoid using tropes in an average text (Lotman 1990: 44). Following such division, Estonian literature might be more or less considered rhetorical and that of Japan - anti-rhetorical. Of course, as Lotman says, these trends cannot exist independently of each other, and in a rhetorical context

"the 'anti-rhetorical' text, consisting of elements of direct, non-figurative semantics, comes to be perceived as a meta-trope, a rhetorical figure which has undergone a secondary simplification" (ibid.).

If we recall haiku's function as a poetical form of opposition, in case of which an anti-rhetoric text which does not direct reader's associations through judging the depicted scene, is opposed to an ideologically biased text with fixed axiology, we might presume that an impersonal Bashō-style haiku would be an ideal basis for the refuge from the rhetorical environment of the social realism ${ }^{6}$. The impression that Estonian haiku might be a form of meta-tropical expression, is also supported by the fact that several critics writing on Estonian haiku repeatedly stress that European tropes, i.e. the metaphors, metonymies and others, do not suit haiku, that authors

\footnotetext{
${ }^{5}$ The question of subject-object relationship of nature and man came under consideration in Japanese literature during the Meiji Period, when the influence of Europe and America led to the emergence of the concept of "individual". As a matter of fact, the term "literature" was also evolving at the time and there were lengthy arguments on whether the haiku should belong to literature at all, because of their inability to convey the "complex feelings of modern human beings" (Beichman 1986: 14; also Keene 1987: 91). The Meiji-era haiku-reformer Masaoka Shiki brings with his works a new psychological complexity into haiku (Beichmann 1986: 68-73). His concept of "shasei" (sketching from the life) actually means "discovering" the landscape as an external object (Karatani 1993). Nevertheless, haiku continues to be ambiguous and avoid European tropes even when depicting personal affairs and not Zen experience.

${ }^{6}$ About the rhetorical nature of the social realism see for example Undusk 1994.
} 
should avoid using them and that haiku might be an escape from Western influences (Haug 1980: 1332; Masing 1989: 1000; Mäger 1980: 251; Raud 1984).

Nevertheless, among the texts themselves there are altogether about twenty meta-rhetorical haiku. For example,

Jaan Kaplinski:

\section{Linalakk tüdruk \\ kingul kase all. Maantee. \\ Südasuvi. Tuul.}

(A flaxen-haired girl /on the hill under the birch. Highway. / Midsummer. Wind).

As it is evident from this text, also the texts where attributes are used are considered among the meta-tropical, since the function of an attribute is not to modify the basic meaning of the word, but to distinguish one extensional class from another (Baevski 1987: 512-513), for example the flaxen-haired girls from the black-haired ones. The rest of the ca 220 texts uses tropes extensively.

There are mainly three ways of using tropes in Estonian haiku. The first is using traditional tropes and clichés and then depoeticising them by turning them upside down, realising an everyday metaphor or aggregating traditional metaphors catachretically. As it was briefly mentioned above, this is not a very productive way of meaning generation and can be seen as typical rather for only two authors using it (Andres Ehin, Sven Kivisildnik) than for Estonian haiku in general.

The second type of texts use metaphors in an ordinary way, using single tropes which have local influence, i.e. the field of influence of a trope does not extend beyond the words it consists of, while the other words in the text can be very well used in their literal meaning. The use of tropes in such texts is not a dominating feature, for example,

Mait Markus:

\section{Lumelaik nutab. \\ Ülane õitseb võsas. \\ Pungad puhkevad.}

(The patch of snow is crying. / Windflower blossoms in the coppice. / The buds are opening).

Here the metaphor 'crying snow' does not have a decisive impact on interpreting the rest of the haiku. Though, of course, as a literary text always functions as a whole, one cannot deny that every part of the poem must inevitably have some impact on the reception of other parts.

In the case of the third and the most usual kind of usage, the rhetorical structure is a dominating feature, and the original and unconventionally connected tropes become a rule. These are the texts of the expanded metaphor where the essence of the first metaphor also determines the essence of the following ones. For example in Mart Raud's

\section{Siniallikul \\ kastsid sa vesivärvid suviseks taevaks}

(At the Blue-spring / you sprinkled the watercolours / into the summer sky), the first part of the word 'blue-spring' causes the use of 'colours' and 'sky' (which is of course blue in summer), and the second part 'spring' brings about 'water(colours)' and 'sprinkling'. Often the influence of the first trope used in a haiku spreads also over the phrases of literal usage, so that the latter also gain some rhetorical characteristics. 
Although such extensive use of tropes in haiku is somewhat surprising in the political context of Estonian literature of the Soviet era, it is certainly to be expected when we consider it in the context of the overall tendencies in the use of poetic techniques in that era. The 1960s are the time for innovation in the employment of figures of speech. The figures become more complicated; their field of influence enlarges; freedom, innovativity and courage in their use become their merit. A figure is the means of cognition, and an ideal figure has to act on the reader's senses. The 1970s and the 1980s see some of the bravura withdrawn from the use of figures and the rise of minimalism, but in principle the core of the new style of figures, developed in the 1960s, remains ${ }^{7}$. (Nagelmaa 1991: 103-105; Kaplinski 1983: 235, 237; Hennoste 1995: 91; see also Ehin 1966).

In the above-mentioned article Yuri Lotman defines a trope as "a pair of mutually non-juxtaposable elements, between which, thanks to the context they share, a relationship of adequacy is established" (Lotman 1990: 37), whereby the second term of the metaphor is "interpreted by reference to the first term" (ibid: 38 ). In his "Lectures on the Structural Poetics" Lotman also states that it is the principle of the artistic text, that it

"requires constant returning to the text, which seems to have already completed its informational role, and comparing it to the following text. By this, in such a process of juxtaposition even the old text uncovers itself anew, revealing the semantic content earlier hidden" (Lotman 1994: 89).

In the light of those two quotes it is of utmost importance to distinguish between Estonian and Japanese way of generating meanings inside a haiku ${ }^{8}$.

Japanese haiku is characterised by a dyadic structure. In addition to being often divided into two parts by a cutting word, kireji, a text usually consists of two elements: the "ground" and the "figure". They seem to be opposed terms on the semantic level, but are not so internally, since oppositions do not exist for the Zen mentality. For example, the "ground" may give an eternal, indestructible, vast and indefinite object, while a "figure" juxtaposes it with a temporal, destructible, tiny and finite object (Ueda 1970: 52), which come to be interconnected only because of the abrupt end, which equalises the positions of the seemingly inconnectable words or word groups, and only in the reader's mind they acquire the nature of a trope (esp. comparison) because of this equalisation ${ }^{9}$.

While Estonian haiku is exactly as short as the Japanese one, it uses its words in a radically different way. As it has already been stated above, Estonian haiku authors abundantly use tropes that are composed inside the text. It means that the rhetorical relationship is given already before the end and this in its turn makes the end less marked than in case of the Japanese haiku. The end in Estonian haiku is not a

\footnotetext{
${ }^{7}$ Although being a part of the innovation process in the use of the figures of speech is a convenient explanation for Estonian haiku's abundant use of tropes, it is certainly not a sufficient one. It is interesting to note that Luiza Lobo has pointed out a similar tendency in Brazilian haiku, where it is, in her words, connected to the Symbolist "approach to poem-making" (Lobo 1995: 100). Still, as Symbolism has never been prevailing here, it cannot be so in the case of Estonian haiku.

${ }^{8}$ Of course, in reality the meaning of the text is produced in co-operation of the meanings created inside the text and between different texts, and differentiating them here with the view of analysing is in any way a simplification.

${ }^{9}$ Much of the same mechanism is described by Kawamoto Kōji, when discussing haiku's ability to generate meanings in its extreme brevity. Although he divides the haiku into two parts in a different way and focuses mainly on generating meaning through literary associations, he similarly notes that the two parts are interconnected only because there is no following text (Kawamoto 1993).
} 
part of the meaning-generation arsenal to the extent it was in case of, for example, Bashō. This, in its turn, significantly reduces the role of the reader.

Imagist poetry also saw haiku as a perfect metaphor, and Ezra Pound developed on its basis the technique of super-position, where the two parts of the text are in a metaphorical relationship, like in the case of Pound's famous

The Apparition of these faces in the crowd;

Petals on a wet, black bough

(cf. e.g. Kawamoto 1993; Miner 1958).

In case of Estonian haiku, it is more common first to give a picture, and then enlarge, comment or explain it with the following images, so that the parts of the texts are rather in metonymical relation than in metaphorical. It is also possible that the authors add a figure after a figure, whereas the elements are in a metonymical relationship with the final picture rather than with each other. For example, a case of explanation,

Mait Markus:

Tuledepaarid

sõidavad läbi saju.

Mees vihmavarjus.

(The pairs of lights / drive through the rain. / A man in the shelter);

a case of addition,

Mart Raud:

Linnud lendavad,

kaasas laulud ja suled, nokad ja küüned

(Birds are flying, / with songs and feathers, / bills and claws).

As it can be noticed here the texts with explanations may sometimes resemble more a riddle than a haiku, except for the 5-7-5 syllable pattern.

Furthermore, there is a considerable number of texts, which form one single proverb-like statement, and in several times such texts approximate again more a witticism than a Bashō-style haiku. For example,

Ellen Niit:

Kajakakisa

vaevalt kuidagi muudab

laevade rändu

("The cry of the sea-gulls / hardly could change somehow / the routs of the ships).

\section{Instead of a conclusion}

When looking at all the differences counted above (those in two last paragraphs being less universal than the earlier), one might first arrive to a question what the Estonian and Japanese haiku have in common.

At a superficial glance it might be said that one common trait is the 5-7-5 syllable pattern from which there are only 21 deviations among 339 texts, and most of these 21 texts differ from the norm only by 1-2 syllables. But on a closer examination it turns out that Estonian haiku, unlike Japanese, does not belong to the syllabic, but rather to the accentual-syllabic system of versification (for a definition see Lotman 1998).

Under the present circumstances it is rather questionable, whether these two phenomena are really one and the same thing. Certainly there are similarities, which 
are more subtle and have therefore remained unnoticed under the cover of the major differences, but it is also certain that the term 'haiku' marks radically different types of texts in Japanese and in Estonian literature. 


\section{References}

Baevski 1987 = Баевский Вадим С. (1987) “Эпитет”. In: Литературный энциклопедический словарь. Москва: Советская энциклопедия, 512-513.

Beichman, Janine (1986). Masaoka Shiki. Tokyo: Kodansha International.

Breslavec 1981 = Бреславец, Татяна И. (1981). Поэзия Мацуо Басё. Москва: Наука.

Eco, Umberto (1981). The Role of The Reader. London: Hutchinson.

Ehin, Andres (1966). "Kujund ja meeled". In: Looming 11: 1768-1775.

Haug, Toomas (1980). "Haikuraamatu puhul”. In: Looming 9: 1332-1334.

Hennoste, Tiit (1995). "Hüpped modernismi poole: Eesti 20. sajandi kirjandusest Euroopa modernismi taustal. 17. loeng". In: Vikerkaar 3: 69-76.

Higginson, William J. (1996). Haiku Seasons: Poetry of the Natural World. Tokyo: Kodansha International.

Kaalep, Ain (1983). "Ikka jälle keelest ja luulest”. In: Sirp ja Vasar 36, September 9: 5.

Kaplinski, Jaan (1983). "Interpretatsioone ja impressioone viimase veerandsajandi luuleilmast". In: Keel ja Kirjandus 5: 232-240.

Karatani, Kōjin (1993). Origins of Modern Japanese Literature. Durham: Duke University Press.

Kawamoto, Kōji (1993). "The Poetics of Short Poems: Haiku and Imagist Poetry”. In: R. K. Thomas (ed.). Poetics of Japanese Literature. Purdue University, 1-12.

Keene, Donald (1987). Dawn to the West: Japanese Literature of the Modern Era. New York: Henry Holt and Company.

Lobo, Luiza (1995). "Haiku in Brazil". In: The Force of Vision, vol 6: Inter-Asian Comparative Literature. Tokyo: Tokyo University Press, 98-107.

Lotman 1994 = Лотман, Юрий М. (1994). “Лекции по структуральной поэтике”. In: Ю. М. Лотман и тартуско-московская семиотическая школа. Москва: Гнозис, 17-257.

Lotman 1996 = Лотман, Юрий М. (1996). “Анализ поэтического текста. Н. А. Заболоцкий "Прохожий"”. In: $O$ поэтах и поэзии. Санкт-Петербург: Искусство-СПБ, 239-252.

Lotman 1998 = Лотман, Михаил (1998). “О системах стихосложения (преимущественно на материале эстонского и русского стиха)”. In: Sign System Studies, vol 26. Tartu: Tartu University Press, 201-255.

Lotman, Yuri (1990). The Universe of Mind. London: I. B. Tauris \& Co. Ltd.

Masing, Uku (1989). “Kaks kirja haikude asjus”. In: Akadeemia 5: 999-1001.

Miner, Earl (1958). The Japanese Tradition in British and American Literature. Princeton, New Jersey: Princeton University Press.

Mäger, Mart (1980). "Haiku Eestis”. In: Kõik siin maailmas: valimik eesti haikusid. Tallinn: Eesti Raamat, 248-253.

Nagelmaa, Silvia (1991). "Luule". In: Eesti kirjanduse ajalugu. Tallinn: Eesti Raamat, 91-119.

Olesk, Sirje (1998). "Eesti kirjanduse ajalugu 1940-1991. Olulist.”. In: Laak, M. (ed.). Traditsioon ja pluralism: kirjanduskonverentside materjale. Tallinn: Tuum, 228-236.

Raud, Rein (1984). “Mõni sõna haikude kohta”. In: Sirp ja Vasar 2 (2058), January 13: 5 . 
Raud, Rein (1997). “Aeg lühiluuletustes, lühiluuletused ajas”. In: Vikerkaar 9: 97101.

Sebeok, Thomas A. (1994). Signs: An Introduction to Semiotics. Toronto: University of Toronto Press.

Shibata, Yoriko (1998). "The Influence of Haiku on Rilke". In: Interlitteraria, vol 3. Tartu: Tartu University Press, 335-345.

Ueda, Makoto (1970). Matsuo Bashō. New York: Twayne Publishers.

Undusk, Jaan (1994). "Stalinismi müstilised ja maagilised märgid". In: Akadeemia 9: $1863-1889$.

Watts, Alan W. (1990). The Way of Zen. Arkana: Penguin Books.

Veidemann, Rein (1996). Ajavahe. Tallinn: Eesti Raamat, 268-279, 287-293.

Velsker, Mart (1998). "Stalinismi võidud ja kaotused kuuekümnendatel aastatel”. In: Vikerkaar 10-11: 119-127.

Yamada-Bochynek, Yoriko (1985). Haiku East and West: A Semiogenetic Approach. Bochum: Studienverlag Brockmeyer. 